\title{
Responding to: Published Views on Toward Understanding the Biology of Crime in Trinidad and Tobago
}

The Editor,

Sir,

Traboulay's exposition on the medicolegal rulings related to the attributes of neurotransmitters and criminal prosecution is indeed, inceptive and inspirational. The indepth treatment of epigenetic influences and evolutionary genetics accent and complement this author's view on the influence of genes on crime. I too, agree that debate needs to be initiated in this area and an in-depth, inceptive approach taken to address the scourge of crime in Trinidad and Tobago. There is no doubt the technology exists to effect a significant change; however, the general acceptance of this technology may not be so easily forthcoming in the Caribbean. The local public's exposure to genetic paradigms related to crime, aside from articles such as these, revolves around the SCI-FI treatment of mutants in the cinema and comic books. Unless personally affected, "in-vitro" fertilization is outside the scope of social debates, much less the discussions of designer babies etc.

Worldwide, the study of behavioural genetics remains a controversial topic, with disagreement not just over the science itself, but even more so about the therapeutic, societal and legal implications. I fear that, from a Caribbean perspective, the idea of behavioural "profiling" may risk being branded as "heresy" by many citizens, in the same manner as Galileo's support of heliocentrism was by the Roman Catholic Inquisition. It is comforting, however, to know that fellow academics share my view that, not only should a biological component to crime be acknowledged, but conversations towards characterizing the trait locally (and even regionally), needs to be conducted. The option, in this author's humble opinion, would be an exponential increase in criminal and deviant behaviours amidst the implementation of more social structures, which would have substantially less impact over time.

Psychopathy is widely regarded as a congenital state characterized by the lack of empathy or moral compass and defined at least partly by genes, in contrast to other forms of sociopathy or antisocial personality disorder (APD), in which environmental factors make a major contribution (1). It is also heritable (2).
While this author is not saying that any single gene alone is necessary, or sufficient to predispose someone to high levels of psychopathic or other traits, genes should, at least, be factored into any intervention strategies employed locally, incorporating both the social and biological determinism perspectives, the latter incorporating the (previously lacking) research findings of the genetic determinants of crime. Of course, psychological perspectives need to be considered as well.

Our local politicians, legal minds and criminologists are in a position similar to that of chemists 100 years ago. The concepts, methods and measuring devices available to geneticists, neuroscientists, endocrinologists etc, have the propensity to do for criminology, what chemistry did for biology. We are at a point in our evolving history where the cultural and intellectual climate must influence the way we approach the study of crime and criminality.

One immediate benefit of using this approach will be the use of appropriate intervention and/or therapy targeted to specific underlying personality tendencies. For example, psychopaths tend not to respond well to punishment because they cannot associate it with acts they do not consider in any way morally wrong (3). But they are more likely to respond to reward. Relationships such as these may help direct punitive measures that are more effective and long-lasting.

In conclusion, I can philosophize that, while the knowledge of gene variants may risk withholding another Pacquiao or Mayweather from the world, the paradoxical situation of allowing another Mengele or Hitler into it is equally devastating.

Keywords: Behavioral genetics, determinism, psychopathy

\section{Emmaunel}

From: Institute of Crime Prevention and Problem Solving and Analytical Health Services, Chaguanas, Trinidad, West Indies. 
Correspondence: Dr D Emmanuel, Analytical Health Services, Suite No 6, Xtra Commercial Center, 37 Eleanore Stree, Chaguanas, Trinidad, West Indies.

Email:derek_emmanuel@yahoo.com

\section{REFERENCES}

1. Fontaine N, Viding E. Genetics of personality disorder. Psychiatry 2008; 7: 137-41.

2. Viding E, Blair RJR, Moffitt TE, Plomin R. Evidence for substantial genetic risk for psychopathy in 7-year olds. J Child Psychol Psychiatry 2005; 46: 592-7.

3. Hunter P. The psycho gene. EMBO Rep 2010; 11: 667-9. 